\title{
MACHINING PARAMETERS INFLUENCING IN ELECTRO CHEMICAL MACHINING ON AA6061 MMC
}

\author{
PARAMETRI STROJNE OBDELAVE, KI VPLIVAJO NA \\ ELEKTROKEMIJSKO STROJNO OBDELAVO AA6061 MMC
}

\author{
Chenthil Jegan Thankaraj Mariapushpam¹, Durairaj Ravindran², Manaharan Dev Anand ${ }^{3}$ \\ ${ }^{1}$ St. Xavier's Catholic College of Engineering, Department of Mechanical Engineering, Kanyakumari District, India \\ ${ }^{2}$ National Engineering College, Department of Mechanical Engineering, K.R.Nagar, Kovilpatti, Thuthukoodi District, India \\ ${ }^{3}$ Noorul Islam Centre for Higher Education, Department of Mechanical Engineering, Kumaracoil, Kanyakumari District, India \\ optrajegan@yahoo.co.in
}

Prejem rokopisa - received: 2015-08-18; sprejem za objavo - accepted for publication: 2015-11-05

\begin{abstract}
In this study the mechanical and microstructural behaviours of AA6061 reinforced with silicon carbide (SiC) and AA6061 reinforced with boron carbide $\left(\mathrm{B}_{4} \mathrm{C}\right)$, obtained from the enhanced stir-casting process, were investigated using scanning electron microscopy (SEM) and X-ray diffraction (XRD) with various weight percentages, i.e., $2.5 \%, 5 \%$ and $7.5 \%$. The testing shows that the tensile and microhardness properties of the AA6061 were improved in both the reinforced aluminium-matrix composites. The influence of the electrochemical machining process parameters like current, voltage, electrolyte concentration, feed rate, gap and flow rate were considered as the input parameters. The output responses are the material removal rate $(M R R)$, the surface roughness $(S R)$ and the radial overcut $(R O C)$. The study shows that the dominant output parameter $M R R$ was directly proportional to the input parameters current, voltage and feed rate. The $S R$ was significantly influenced by the input parameters current, feed rate and gap. The ROC was considerably balanced by the input parameters current and feed rate.

Keywords: metal-matrix composites, material removal rate, electrochemical machining, surface roughness, radial overcut
\end{abstract}

V študiji so bile preiskovane mehanske lastnosti in mikrostruktura AA6061, izdelanega z naprednim postopkom ulivanja s premešavanjem in ojačanega $\mathrm{z}$ različnim masnim deležem silicijevega karbida $(\mathrm{SiC})$ ali borovega karbida $\left(\mathrm{B}_{4} \mathrm{C}\right)(2,5 \%, 5 \%$ in $7,5 \%$ ). Preiskave so bile izvedene s pomočjo vrstičnega elektronskega mikroskopa (SEM) in z rentgensko difrakcijo (XRD). Preizkušanje kaže, da sta natezna trdnost in mikrotrdota AA6061 narasli pri obeh vrstah kompozita na osnovi aluminija. Za vpliv vhodnih procesnih parametrov pri elektrokemijski strojni obdelavi so bili upoštevani: tok, napetost, koncentracija elektrolita, hitrost podajanja, reža in hitrost pretoka. Izhodni odgovori so bili: hitrost odstranjevanja materiala $(M R R)$, hrapavost površine $(S R)$ in povečanje radiusa $(R O C)$. Studija kaže, da je prevladujoči izhodni parameter $M R R$ neposredno proporcionalen vhodnim parametrom; toku, napetosti in hitrosti podajanja. Na $S R$ so močno vplivali vhodni parametri: tok, hitrost podajanja in reža. $R O C$ je bil posebej uravnotežen z vhodnima parametroma, tokom in hitrostjo podajanja.

Ključne besede: kompoziti na kovinski osnovi, hitrost odstranjevanja materiala, elektrokemijska strojna obdelava, hrapavost površine, povečanje radiusa

\section{INTRODUCTION}

Electrochemical machining (ECM) is a well-known process used for the manufacture of various sophisticated parts, such us turbine blades, rifle bores, hip-joint implants, micro-components as well as many other applications. ECM provides an economical and effective method for shaping high-strength, heat-resisting materials into complex shapes and producing high-quality products from composites and other hard materials. ${ }^{1}$ In ECM the machining is done at low voltage compared to other processes with a high metal removal rate. It is suitable for mass production work and low labour requirements. ECM is one of the most widely used advanced machining processes to make complicated shapes of varying sizes with electrically conducting, but difficult to machine, materials such as super alloys, Ti alloys, alloy steel, tool steel, stainless steel, etc. ${ }^{2}$ These materials are extensively used in aerospace, automobile, space, nuclear, defence, cutting tools, dies and mould making applications. The material used for ECM tools should be electrically conductive and easily machinable to the required geometry. The various materials used for this purpose include copper, brass, stainless steel, titanium, and copper-tungsten. Tool insulation controls the side electrolyzing current and hence the amount of oversize. Spraying or dipping is generally the simplest method of applying insulation. Teflon, urethane, phenol, epoxy, and powder coatings are commonly used for tool insulation. ${ }^{3}$

The material removal rate of an aluminium workpiece has been obtained by electrochemical machining using a $\mathrm{NaCl}$ electrolyte at different current densities and compared with the theoretical values. ${ }^{4}$ It has been observed that the resistance of the electrolyte solution decreases sharply with increasing current densities. The increase in the peak current increases the $M R R$, TWR and $R O C$ significantly in a nonlinear fashion, $M R R$ and $R O C$ increased with the increase in the pulse on time and the gap voltage was found to have some effect on the three responses. ${ }^{5,6}$ The influence of electrochemical process parameters such as the applied voltage, electrolyte 
concentration, electrolyte flow rate and tool feed rate on the metal removal rate and surface roughness to fulfil the effective utilization of electrochemical machining can be used. $^{7}$

For non-passivating electrode systems, the reduction in electrolyte concentration and an increase in its temperature improve the quality of surfaces. ${ }^{8}$ The use of a gap voltage between $20 \mathrm{~V}$ and $25 \mathrm{~V}$ saves energy and reduces the production cost. ${ }^{9}$ The machining current increases linearly with the tool feed rate. Sparking causes damage to both the tool and the workpiece due to the critical feed rate, which is because of the rapid moment of the tool towards the workpiece. The feed rate was the main parameter affecting the material removal rate. ${ }^{10}$ So it is better to maintain the feed rate according to the anodic dissolution rate for proper machining. ${ }^{11}$ The electrolyte temperature, pressure variations in the inter electrode gap and the choice of an optimum gap voltage also avoid the occurrence of sparking and the consequent loss of the tool and workpiece. ${ }^{12}$

A metal-matrix composite (MMC) contains matrix materials where reinforcements can be made from polymers, ceramics or metals. MMCs are divided into composites reinforced by fibres (fibrous composites) and composites filled with fine particles that are insoluble in the base-metal-strengthened composites. ${ }^{13}$ Aluminiummatrix composites consist of a uniform distribution of strengthening ceramic particles embedded within an aluminium matrix. Many researchers discovered aluminium materials and found they exhibit higher strength and stiffness, in addition to isotropic behaviour at a lower density, when compared to the un-reinforced aluminium matrix. ${ }^{14-16}$ The ceramic's ability to withstand high velocity impacts and the high toughness of the metal matrix, which helps in preventing total shattering, are one of the main reason for AMC strength. The composites possess good mechanical properties at high temperature and thus an AMC can be a favourite choice for cost-effective alternatives and shows potential in large-scale applications such as automotive, aerospace and airframe applications. It is proved that among the aluminium alloys, AA6061 was quite a popular choice as a matrix material. ${ }^{17}$ In our previous work the ductile and microhardness properties of silicon-carbide, boron-carbide-based AMCs were analysed and it was reported that both AMCs are suitable for unconventional machining. ${ }^{18}$ The fabrication of a MMC with various ceramic particles such as $\mathrm{Si}_{3} \mathrm{~N}_{4}, \mathrm{TiB}_{2}, \mathrm{~B}_{4} \mathrm{C}$ and machining the fabricated MMC individually was analysed by many researchers. ${ }^{19-21}$

Fabrication by the pressure-less infiltration process under a nitrogen gas atmosphere and the grinding of the aluminium-based MMC reinforced with $\mathrm{SiC}$ particles show that the physical and chemical compatibility between the $\mathrm{SiC}$ particles and the Al matrix is the main concern in the preparation of SiC/Al composites. ${ }^{22}$ Due to the low coefficients of thermal expansion for maxi- mizing heat dissipation and minimizing thermal stress, high-performance thermal management materials are most commonly used in the packaging of microprocessors, power semiconductors, high-power laser diodes, light-emitting diodes and micro-electromechanical systems..$^{23,24}$

Limited research work has been reported on AMCs reinforced with $\mathrm{B}_{4} \mathrm{C}$ due to higher raw-material costs and poor wetting. Stir casting is accepted as a general commercial technique for producing MMCs. ${ }^{25}$ Boron carbide was an attractive reinforcement for aluminium and its alloys, showing many of the mechanical and physical properties required of an effective reinforcement, in particular high stiffness and hardness. These factors combined with a density less than that of solid aluminium indicate that large specific property improvements are possible. ${ }^{26}$ Boron-carbide-particulate-reinforced aluminium composites possessed a unique combination of high specific strength, high elastic modulus, good wear resistance and good thermal stability compared to the corresponding non-reinforced matrix alloy system. ${ }^{27}$

This study covers the fabrication and machining of an aluminium-based MMC reinforced with SiC particles. The mechanical properties of the fabricated MMC and the influence on the ECM machining process parameters were analysed with experiments. The mechanical and microstructural properties of AA6061 reinforced with silicon carbide and AA6061 reinforced with boron carbide attained from the enhanced stir casting method were discussed. The influence of the ECM process parameters current, voltage, electrolyte concentration, feed rate, gap and flow rate on the predominant output parameters material removal rate, surface roughness and radial overcut were also analysed.

\section{SPECIMEN PREPARATION USING AA6061}

The matrix material for the study was AA6061. The composite material consists of AA6061 alloy as a matrix material reinforced with three different weight percentage of $\mathrm{SiC}$ and varying weight percentages of $\mathrm{B}_{4} \mathrm{C}$ $(2.5 \%, 5 \%$ and $7.5 \%)$ prepared through the enhanced stir-casting technique. The $\mathrm{SiC}$ has better mechanical properties such as high hardness, low density and retains its properties even at higher temperatures. The $\mathrm{B}_{4} \mathrm{C}$ is a hard reinforcement particle that has neutron absorbing characteristics in nature. The percentage of silicon content in AA6061 is high compared to other aluminium alloys and its melting point is low. The chemical composition of AA 6061 by weight percentage is $\mathrm{Cu} 0.1 \%$, Mg $0.4 \%$, Si $10 \%$, Mn $0.3 \%$, Ni $0.1 \%$, Zn $0.1 \%$, Pb $0.05 \%$ and Sn $0.2 \%$. The average particle size of the SiC is 200 mesh, with a density of $3.2 \mathrm{~g} / \mathrm{cm}^{-3}$ and a thermal conductivity $3.2 \mathrm{~W} \mathrm{~cm}^{-1} \mathrm{~K}^{-1}$ and also an average particle size of the $\mathrm{B}_{4} \mathrm{C}$ is 200 mesh.

The test specimens were prepared using the simplest and most commercially used technique known as 
enhanced stir-casting technique. In the stir-casting process the pre-heated ceramic particles were mixed with a vortex of molten alloy created by the rotating impeller. As a result of the interaction between the suspended ceramic particles and the moving solid-liquid interface during solidification, there was a possibility of inhomogeneity in the reinforcement distribution. Generally, it is possible to incorporate up to $30 \%$ of ceramic particles in the size range $5 \mu \mathrm{m}$ to $100 \mu \mathrm{m}$ in a variety of molten aluminium alloys. AA6061 was placed inside the crucible and the temperature was set $1000{ }^{\circ} \mathrm{C}$. Some $1 \%$ of the degasser Hexa Chloro Ethane was added to the melted AA6061. The molten metal was stirred and the crucible was held with forks to eliminate the gases. The same process was repeated for various weight percentages of SiC-reinforced AMC and $\mathrm{B}_{4} \mathrm{C}$-reinforced AMC.

\section{ELECTROCHEMICAL MACHINING}

For this experiment the whole work was carried out with an ECM set up having a power supply of $415 \mathrm{~V}$, 3-phase AC, $50 \mathrm{~Hz}$ and it consists of three major sub systems: the machining cell, the control panel and the electrolyte circulation tank. The parameter that is able to change the output parameters by increasing and decreasing the level is known as the controlling parameters or the input parameters. In this paper the considered input parameters are the current, voltage, electrolyte concentration, feed rate, gap and flow rate. The output parameters considered are the MRR, SR and ROC. The various levels of input parameters selected for the machining are listed in Table $\mathbf{1 .}$

Table 1: Input parameters and levels

Tabela 1: Vhodni parametri in njihovi nivoji

\begin{tabular}{|c|c|c|c|c|c|}
\hline \multirow{2}{*}{ Variables } & \multicolumn{5}{|c|}{ Values of different levels } \\
\cline { 2 - 6 } & 1 & 2 & 3 & 4 & 5 \\
\hline Current (A) & 90 & 120 & 150 & 180 & 210 \\
\hline Voltage (V) & 8 & 10 & 12 & 14 & 16 \\
\hline $\begin{array}{c}\text { Electrolyte } \\
\text { concentration (g/L) }\end{array}$ & 3.34 & 6.67 & 10 & 13.34 & 16.67 \\
\hline Feed rate (mm/min) & 0.1 & 0.2 & 0.3 & 0.4 & 0.5 \\
\hline Gap (mm) & 0.1 & 0.2 & 0.3 & 0.4 & 0.5 \\
\hline
\end{tabular}

\subsection{Machining process}

The machine cell has a tool area of $300 \mathrm{~mm}^{2}$, a cross-head stroke $150 \mathrm{~mm}$, a job holder $100 \mathrm{~mm}$ opening, $50 \mathrm{~mm}$ depth and $100 \mathrm{~mm}$ width. A DC servo-type tool feed motor was used for the tool movement. The control panel consists of an electrical output rating ranging from $0 \mathrm{~A}$ to $300 \mathrm{~A} \mathrm{DC}$ for any voltage from $0 \mu \mathrm{m}$ to $20 \mathrm{~V}$, tool feed of 0.2 to $2 \mathrm{~mm} / \mathrm{min}$, while the supply given to the machining was 3-phase AC with $50 \mathrm{~Hz}$. The specimen to be machined was fixed in the machine vice. The tool was brought near the job with the help of press buttons provided on the control panel and a table-lifting arrangement, maintaining a particular gap.
The tool progress was maneuverered vertically by the servomotor and is governed by a microcontroller-based programmable drive. The c cathode tool is made of non-reacting copper material. The process parameters like current, voltage, electrolyte concentration, feed rate, gap and flow rate were set. The process was started in the presence of an electrolyte flow. This electrolyte flow was adjusted using a flow-control valve. After the desired time interval, a hooter gives an indication of the completion of the time and the process. The specimen prepared was a cylindrical blank of $16 \mathrm{~mm}$ in diameter and $32 \mathrm{~mm}$ in height. The electrolyte composition used was $\mathrm{NaCl}$ solution.

\section{RESULTS AND DISCUSSION}

The hardness of the specimens was measured by a Rockwell hardness and a tensile test. The Rockwell hardness number measures the overall response of the material and it is relatively insensitive to localized effects. The Rockwell scale is a hardness scale based on the indentation hardness of a material. The Rockwell test determines the hardness by measuring the depth of the penetration of an indenter under a large load compared to the penetration made by a preload. The chief advantage of Rockwell hardness is its ability to display hardness values directly, thus obviating tedious calculations involved in other hardness-measurement techniques. The Rockwell Hardness number for AA 6061 and the other experimental MMC are shown in Figure 1. It is clear that the hardnesses of the MMCs are closer to one another, but the values are high compared with AA 6061.

For microstructure analysis the machined samples were polished using silicon carbide paper $(60,80,120$, 220 and 400) grit and finally using a soft cloth with fine alumina powder as a slurry. Kerosene was used for cleaning and polishing to prevent the embedding of foreign particles in the sample. The samples were then etched using the modified diamond paste for $140 \mathrm{~s}$. The long etching time was due to the large oxide content of

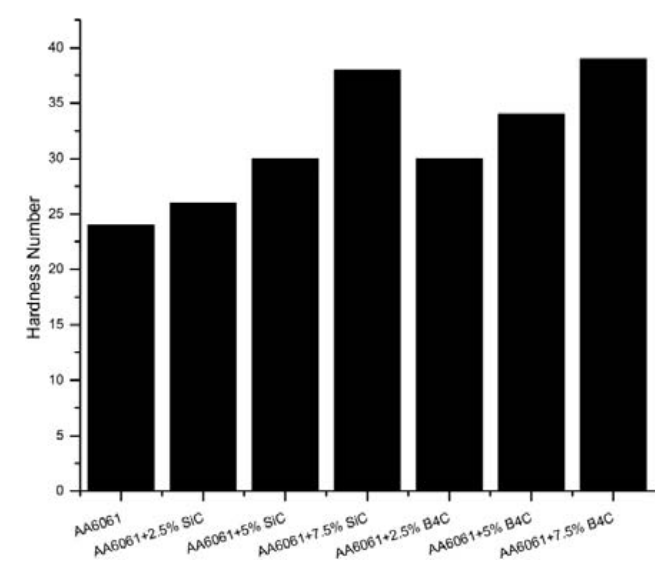

Figure 1: Rockwell hardness number for experimental samples Slika 1: Rockwell trdota preizkusnih vzorcev 

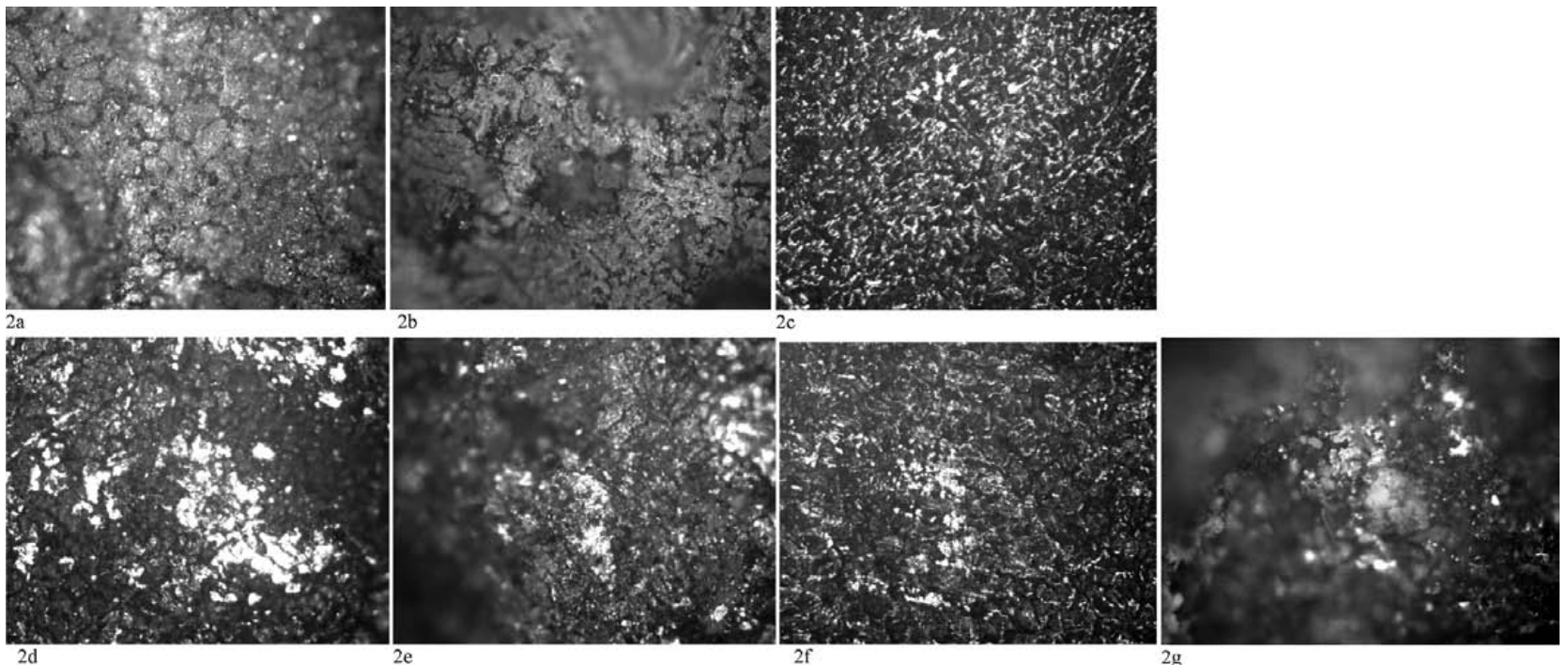

Figure 2: Light microscope (20x) images of seven samples showing the distribution of the reinforcement in the matrix: a) AA6061, b) AA6061 + $2.5 \% \mathrm{SiC}, \mathrm{c}) \mathrm{AA} 6061+5 \% \mathrm{SiC}, \mathrm{d}) \mathrm{AA} 6061+7.5 \% \mathrm{SiC}$, e) AA6061 + $2.5 \% \mathrm{~B}_{4} \mathrm{C}$, f) AA6061 + $5 \%$ B 4 C, g) AA6061 + $7.5 \% \mathrm{~B}_{4} \mathrm{C}$ Slika 2: Svetlobna mikroskopija (20x) sedmih vzorcev, ki kaže razporeditev delcev za utrditev v osnovi: a) AA6061, b) AA6061 + 2,5\% SiC, c) $\mathrm{AA} 6061+5 \% \mathrm{SiC}$, d) $\mathrm{AA} 6061+7,5 \% \mathrm{SiC}$, e) $\mathrm{AA} 6061+2,5 \% \mathrm{~B}_{4} \mathrm{C}$, f) $\left.\mathrm{AA} 6061+5 \% \mathrm{~B}_{4} \mathrm{C}, \mathrm{g}\right) \mathrm{AA} 6061+7,5 \% \mathrm{~B}_{4} \mathrm{C}$

the aluminium powder. The light microscope photographs of the seven combinations of composite samples using an optical microscope of $20 \times$ lens are shown in Figure 2. Figure 2a shows various elements present in AA6061. Figures 2b to 2d represents AA6061+ reinforced silicon carbide particles. AA6061+ reinforced boron carbide particles are shown in Figures $2 \mathbf{d}$ to $\mathbf{2 f}$. It can be shown that the silicon carbide particles and boron carbides are homogenously distributed in the aluminium matrix.

Scanning electron microscopy (SEM) was used to reveal the morphological features in the machined samples. For the study of their microstructure the specimen preparation or polishing is important. The procedure for preparing the specimen involved the selection of the specimen and the mounting of the specimen in the machine, obtaining a flat specimen surface, intermediate and fine grinding, rough polishing using diamond powder with an oil-soluble paste, fine polishing with alumina powder along with distilled water and etching using dilute hydrofluoric acid. The morphological structure of the AMC was obtained using a ZEISS (NIIST) SEM at an accelerating voltage of $20 \mathrm{kV}$. The AA6061 specimens were mounted with conductive adhesives and coated with gold powder. Then, the SEM images were taken at the centre of the machined surface of the sample specimen.

From the above examination both MMCs exhibited similar microstructural features in terms of homogeneous particle distributions associated with similar carbide particle sizes. The SEM analysis of the $\mathrm{B}_{4} \mathrm{C}$-reinforced composites and SiC-reinforced composites exhibited very similar microstructures. However, it was possible to observe some large size pores that were not in the $\mathrm{B}_{4} \mathrm{C}$-reinforced composites. The distribution of the particles was also altered by the growth of the grains. In the $\mathrm{B}_{4} \mathrm{C}$-reinforced $\mathrm{MMC}$ microstructure both coarser grains and finer grains were identified, but the grain size
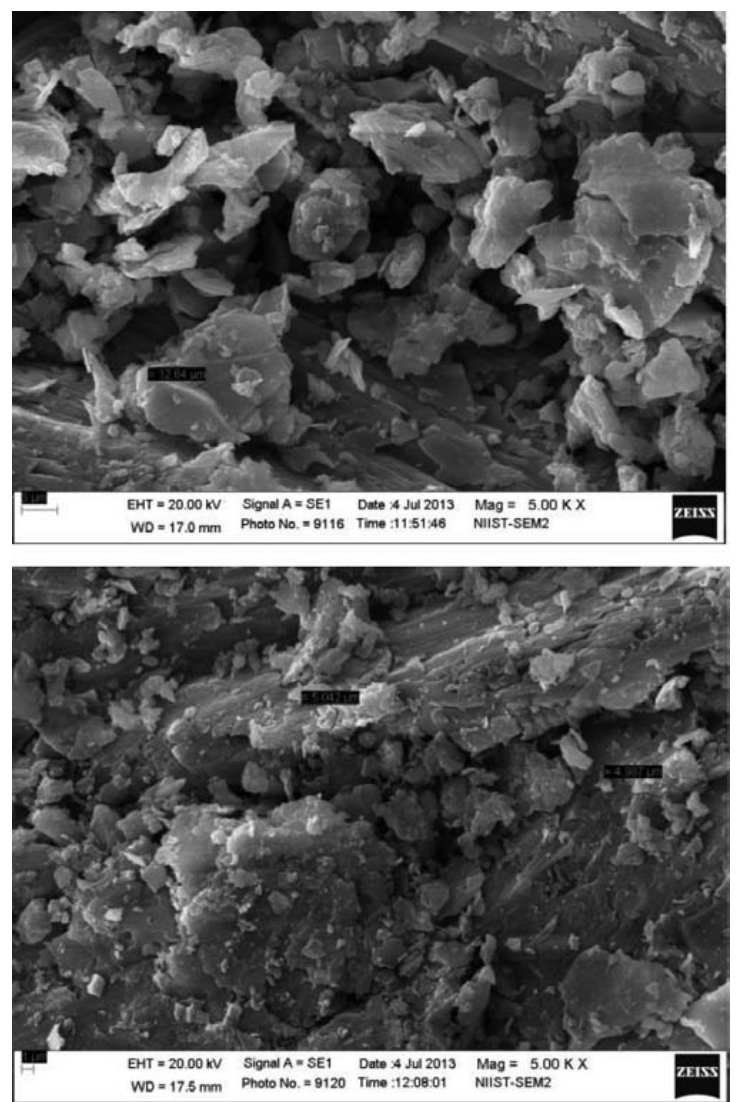

Figure 3: SEM microstructure of: a) SiC-reinforced AA6061 and b) $\mathrm{B}_{4} \mathrm{C}$-reinforced AA6061

Slika 3: SEM-posnetek mikrostrukture: a) AA6061, ojačan s SiC in b) AA6061, ojačan z B 4 C 
was less compared to that of SiC. Similarly, the pore size was also less for the $\mathrm{B}_{4} \mathrm{C}$-reinforced MMC.

The SEM microstructure of the AMCs is shown in Figure 3. From the Figures $\mathbf{3 a}$ and $\mathbf{3 b}$ it is evident that the distributions of the $\mathrm{SiC}$ and $\mathrm{B}_{4} \mathrm{C}$ particles were homogeneous in the AA6061. Most of the ceramic particles were found within the grain boundaries. The distribution of the particles becomes intra granular. The basic atomic structure of AA6061 is body-centred cubic, so that the $\mathrm{B}_{4} \mathrm{C}$ particles were bonded together in reinforcement. Good wettability was also seen in both MMCs, but it was especially high in the $\mathrm{B}_{4} \mathrm{C}$.

To determine the rate of penetration of each aluminium alloy, a series of partial infiltrations were performed in order to study the growth rate at short times (less than $2 \mathrm{~h}$ ). XRD micro-diffraction of the SiC-reinforced $\mathrm{AMC}$ and the $\mathrm{B}_{4} \mathrm{C}$-reinforced $\mathrm{AMC}$ was shown in Figure 4.

The XRD peak list of the SiC-reinforced AA6061 and $\mathrm{B}_{4} \mathrm{C}$-reinforced AA6061 are listed in Tables $\mathbf{2}$ and 3, respectively.

Table 2: Peak list for $\mathrm{SiC}$ reinforced AA6061

Tabela 2: Seznam vrhov pri AA6061, ojačanem s SiC

\begin{tabular}{|c|c|c|c|c|}
\hline $\begin{array}{c}\text { Pos. } \\
2 \theta\left(^{\circ}\right)\end{array}$ & $\begin{array}{c}\text { Height } \\
(\mathrm{cm})\end{array}$ & $\begin{array}{c}\text { FWHM } \\
2 \theta\left(^{\circ}\right)\end{array}$ & $\begin{array}{c}\text { d-spacing } \\
(\mathrm{nm})\end{array}$ & $\begin{array}{c}\text { Rel. Int. } \\
(\%)\end{array}$ \\
\hline 28.4044 & 59.37 & 0.0816 & 0.313967 & 8.57 \\
\hline 38.4426 & 692.59 & 0.1632 & 0.233979 & 100.00 \\
\hline 44.6516 & 307.84 & 0.1632 & 0.202778 & 44.45 \\
\hline 47.2508 & 38.12 & 0.1224 & 0.192212 & 5.50 \\
\hline 49.0100 & 4.93 & 0.0816 & 0.185716 & 0.71 \\
\hline 56.0546 & 19.32 & 0.2856 & 0.163931 & 2.79 \\
\hline 57.6437 & 0.75 & 0.2448 & 0.159784 & 0.11 \\
\hline 65.0870 & 156.16 & 0.1224 & 0.143194 & 22.55 \\
\hline 78.1848 & 161.46 & 0.2448 & 0.122159 & 23.31 \\
\hline 82.3912 & 47.66 & 0.2040 & 0.169540 & 6.88 \\
\hline 87.9251 & 6.83 & 0.4896 & 0.110964 & 0.99 \\
\hline
\end{tabular}

Table 3: Peak List for $\mathrm{B}_{4} \mathrm{C}$ reinforced AA6061

Tabela 3: Seznam vrhov pri AA6061, ojačanem z B ${ }_{4} \mathrm{C}$

\begin{tabular}{|c|c|c|c|c|}
\hline $\begin{array}{c}\text { Pos. } \\
2 \theta\left({ }^{\circ}\right)\end{array}$ & $\begin{array}{c}\text { Height } \\
(\mathrm{cm})\end{array}$ & $\begin{array}{c}\text { FWHM } \\
2 \theta\left(^{\circ}\right)\end{array}$ & $\begin{array}{c}\text { d-spacing } \\
(\mathrm{nm})\end{array}$ & $\begin{array}{c}\text { Rel. Int. } \\
(\%)\end{array}$ \\
\hline 28.5168 & 55.08 & 0.1632 & 0.312755 & 5.71 \\
\hline 36.5506 & 6.86 & 0.1224 & 0.245644 & 0.71 \\
\hline 38.5654 & 963.85 & 0.1632 & 0.233262 & 100.00 \\
\hline 44.8543 & 372.10 & 0.1836 & 0.201909 & 38.61 \\
\hline 47.3974 & 42.42 & 0.1632 & 0.191651 & 4.40 \\
\hline 56.2284 & 12.82 & 0.3264 & 0.163466 & 1.33 \\
\hline 65.2212 & 206.18 & 0.0816 & 0.142932 & 21.39 \\
\hline 76.4518 & 7.85 & 0.3264 & 0.124490 & 0.81 \\
\hline 78.3073 & 240.23 & 0.1632 & 0.121998 & 24.92 \\
\hline 82.5530 & 64.93 & 0.2448 & 0.116766 & 6.74 \\
\hline 83.4711 & 3.89 & 0.4080 & 0.115714 & 0.40 \\
\hline 88.0604 & 10.43 & 0.3264 & 0.110828 & 1.08 \\
\hline
\end{tabular}

From Figure 4 it was observed that the waves were almost the same and symmetrical. The ambiguous structure was available in both AMCs. As compared to the
SiC-reinforced particle, the other one possessed good hardness and an even distribution of particles. The starting angle was also high for the $\mathrm{B}_{4} \mathrm{C}$-reinforced AA6061. In the SiC-reinforced AA6061, the $\mathrm{SiC}$ particle peaks were identified at angles of 28.4044, 44.6516, 49.0100, 57.6437, 65.0870 and 87.9251. The remaining peak values in Table 3 and 4 were related to the AA6061 alloy. Similarly, in the $\mathrm{B}_{4} \mathrm{C}$-reinforced AA6061, the $\mathrm{B}_{4} \mathrm{C}$ particle peaks were obtained at angles of 28.5168, $36.5506,44.8543,56.2284,65.2212,76.4518$ and 88.0604 .

The ductility of the MMC was improved by the addition of ceramic particles with AA6061. The stress vs. elongation analyses of the AA6061 samples were compared with the AA6061 + SiC MMC, and it was shown in Figure 5. From Figure 5a it was noted that the strength of the specimen increases with an increase in the addition of silicon carbide particles. The maximum strength was obtained for sample 3, with aluminium and $\mathrm{SiC}$, in a ratio of 100:7.5. Similarly, for the AA6061+ $\mathrm{B}_{4} \mathrm{C}$ MMC samples the results were shown in Figure $\mathbf{5 b}$. In AA6061 + $\mathrm{B}_{4} \mathrm{C}$ MMC also better tensile strength was obtained with high percentage of $\mathrm{B}_{4} \mathrm{C}$ reinforcement. From the analysis it was concluded that the ductile nature of AA6061 increased with the addition of $\mathrm{SiC}$ and $\mathrm{B}_{4} \mathrm{C}$ particles.
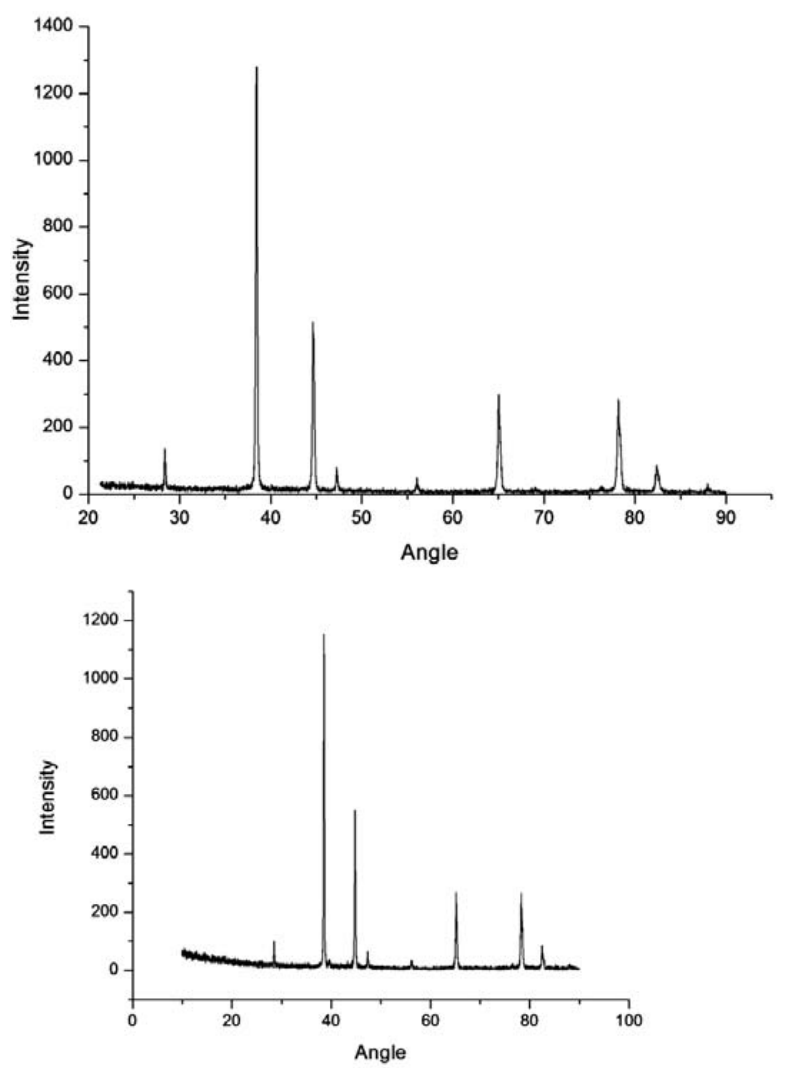

Figure 4: XRD patterns of: a) SiC-reinforced AA6061 and b) $\mathrm{B}_{4} \mathrm{C}$-reinforced AA6061

Slika 4: Rentgenograma: a) AA6061, ojačanega z $\mathrm{SiC}$ in b) AA6061, ojačanega $\mathrm{z} \mathrm{B}{ }_{4} \mathrm{C}$ 

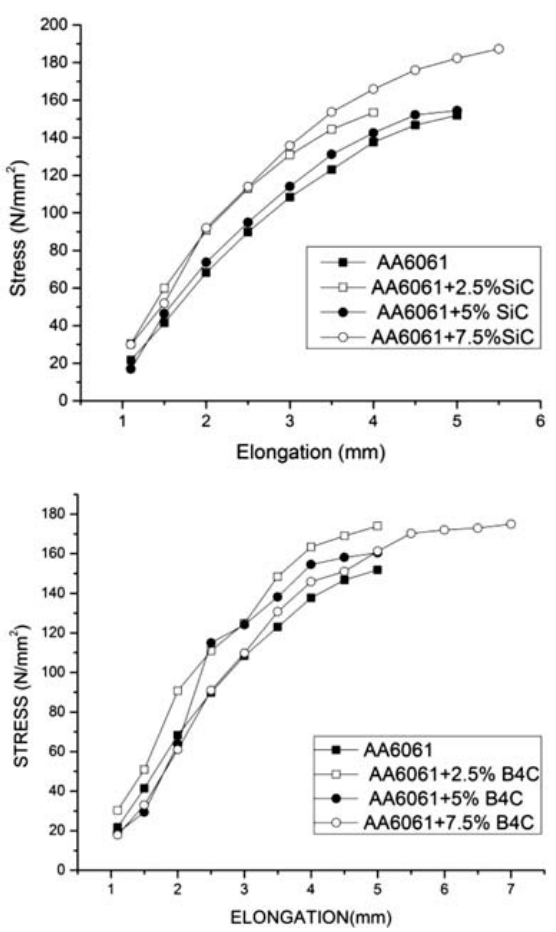

Figure 5: Stress vs. elongation of: a) SiC-reinforced AA6061 and b) $\mathrm{B}_{4} \mathrm{C}$-reinforced AA6061

Slika 5: Napetost v odvisnosti od raztezka: a) AA6061, ojačan z SiC in b) AA6061 ojačan $\mathrm{z} \mathrm{B} 4$

The tensile strength vs. strain analysis of the samples is shown in Figure 6 from which it is noted that the ultimate strength, plasticity and elasticity increased with the percentage of added ceramics. The ultimate point and yield point of the $\mathrm{B}_{4} \mathrm{C}+\mathrm{AA} 6061 \mathrm{MMC}$ were high compared to those of the $\mathrm{SiC}+\mathrm{AA6061} \mathrm{MMC}$. The ductility of both MMCs were high and it can be treated using unconventional machining process as well as conventional machining, and also the workability of the material was very good. Thus SiC-reinforced AA6061 and $\mathrm{B}_{4} \mathrm{C}$-reinforced AA6061 MMC were suited for metal-forming processes such as hot and cold forging, rolling, drawing and spinning.

\subsection{Factors affecting ECM process parameters}

\subsubsection{Factors influencing the material removal rate}

In ECM the current is the major influencing parameter on the $M R R$ of aluminium-based alloys. The values of the $M R R$ obtained in experimentation with different levels of current for the selected samples were shown in Figure 7a. From Figure 7a it was observed that when the current was less the MRR was also less. The AA6061 + $7.5 \% \mathrm{~B}_{4} \mathrm{C}$ gave a lower MRR compared to AA6061 + $7.5 \% \mathrm{SiC}$. When the current was low the material removal rate was low and it gradually increased with increases in the current. A high current will lead to more material removal and optimum material removal appeared at a current value of 150 A. For better ECM indices, higher accuracy, and a better surface finish, it is

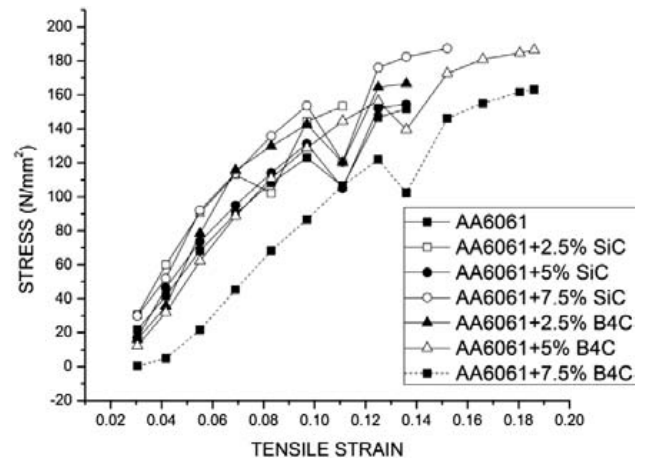

Figure 6: Stress strain diagram of MMC samples Slika 6: Diagram odvisnosti napetost-raztezek MMC vzorcev

essential to choose the proper current density. Low values of current efficiency may indicate a failure to choose the optimum machining conditions that lead to high removal rates and surface roughness.

The influence of voltage over $M R R$ for different samples is shown in Figure 7b. From the graph it was clear that the material removal rate was proportional to rate of change of voltage. When the maximum voltage was applied in between the workpiece and the tool, the maximum material can be removed from the workpiece. If the potential differences in between the copper electrode and aluminium alloys were very low, minimum material removal occurred from the workpiece.

The influence of electrolyte concentration over $M R R$ is shown in Figure 7c. For the consideration of electrolyte concentration, best material removal occurred at a $10 \mathrm{~g} / \mathrm{L}$ concentration. A very low electrolyte concentration produced minimum material removal due to the lack of ionic particles present in the electrolyte. At high range values the ionic concentration was high and the reaction phase at this stage was lagging. Hence, a lower rate of material removal was caused at a high concentration of electrolyte than with the medium electrolyte concentration of $10 \mathrm{~g} / \mathrm{L}$.

The influence of feed rate on $M R R$ is shown in Figure 7d. The directly proportional effect was shown in discussion of the feed rate of the tool on the aluminium alloys. When the feed rate was $0.1 \mathrm{~mm} / \mathrm{min}$, then material removal was minimum. This process gradually increased with increases in the feed rate. It was a maximum at the maximum feed rate of $0.5 \mathrm{~mm} / \mathrm{min}$.

The influence of the gap on MRR is shown in Figure 7e. The gap plays a vital role in electrochemical machining. In electrochemical machining there is no direct physical contact in between the copper electrode and the aluminium workpiece. The reaction was carried out in the presence of an electrolyte that was circulated in between the tool and the workpiece. Therefore, to set the correct gap is an important factor to produce high material removal from the workpiece. In our experiment the maximum material removal could be obtained from the gap with an optimal value at $0.3 \mathrm{~mm}$. Only a minimum amount of material was removed from the workpiece at a 
gap of $0.5 \mathrm{~mm}$. If the gap is a maximum then a lack of reaction will be carried out in between the tool and the minimum $M R R$ will be obtained in the workpiece.

The influence of flow rate on $M R R$ is shown in Figure 7f. The electrolyte flow rate across the tool and the workpiece stamped the noted impressions. During machining the chips were formed on the surface of the workpiece. Electrolyte flow plays the major role in the material removal process with the removal of contaminated chip particles presented on the surface of the machining area. If the flow rate of the electrolyte is too low to splash out the removed chips material on the machined surface, then the minimum amount of material will be removed from the workpiece. From Figure 7f it is clear that the material removal rate was increased by increasing the flow of electrolyte. The maximum flow rate can be obtained from $8 \mathrm{~L} / \mathrm{min}$. Beyond this level it was slightly reduced due to the high flow of electrolyte, which will cause a lean electrolyte concentration.

\subsubsection{Factors influencing surface roughness}

Generally the ECM process is used for the machining of hard materials with good surface finish. But material removal rate and surface roughness are inversely proportional to each other. Therefore, if the material removal rate is high, a poor surface finish will be obtained in the machining process.

The influence of current on the $S R$ for the selected samples is shown in Figure 8a. It was found that there was an inverse effect between the surface roughness and the current. At low current conditions a good surface finish was obtained and it was gradually decreased with an increase in the current. At high current conditions the least surface roughness was obtained. The best value of surface roughness was achieved at minimum material removal and with respect to the hardness of material.

The influence of voltage on the $S R$ for AMCs is shown in Figure 8b. If the potential difference in between the electrode and the workpiece is very high, then a poor surface roughness can be achieved from the alumimium workpiece. At low voltage the surface finish was high, and it was slightly increased at $10 \mathrm{~V}$. Then it was smoothly reduced with an increase in the voltage and finally poor surface roughness occurred due to the maximum voltage level.

The SR obtained at the different levels of electrolyte concentration for selected samples is shown in Figure 8c. In the figure the surface roughness and electrolyte concenration were directly proportional to each other. If the electrolyte concentration was less, a poor surface finish obtained. It is increased with increasing the concentration of electrolyte. A high range of surface roughness can be achieved at a high electrolyte concentration. It was mainly due to the lubrication and good reaction between the electrode and the workpiece.

The influence of feed rate on $S R$ is shown in Figure 8d. For considering the surface roughness feed rate and inter electrode gap plays the same role. A good surface
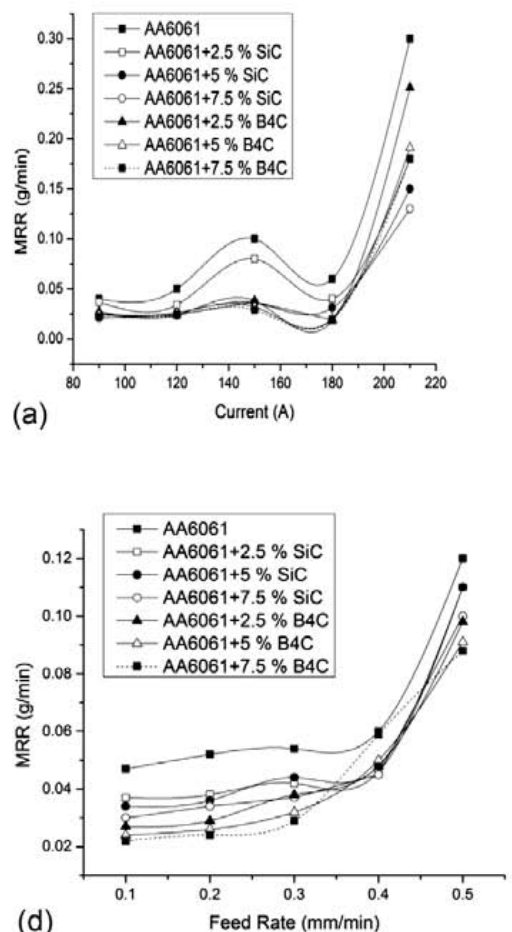
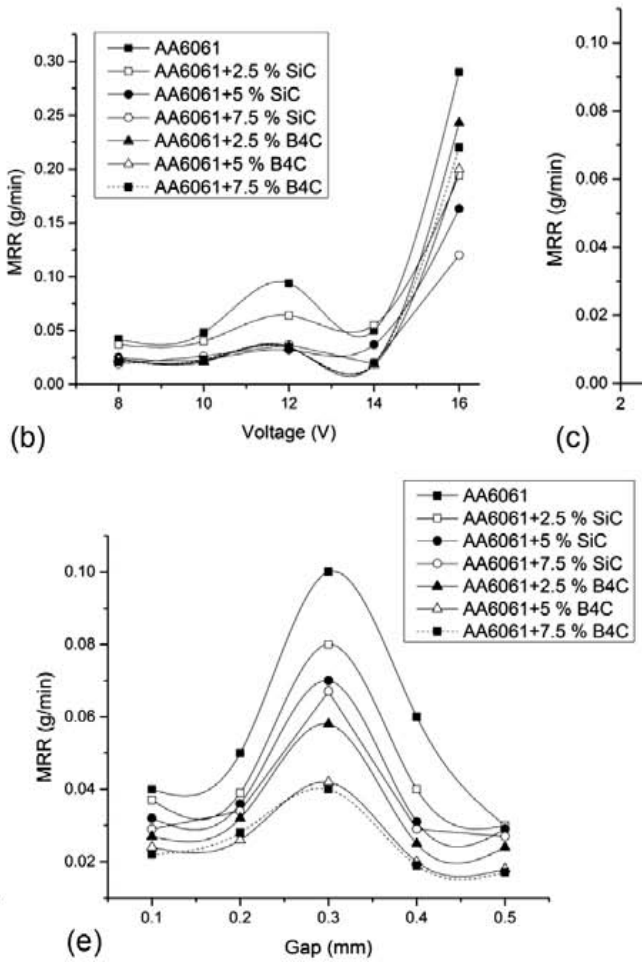
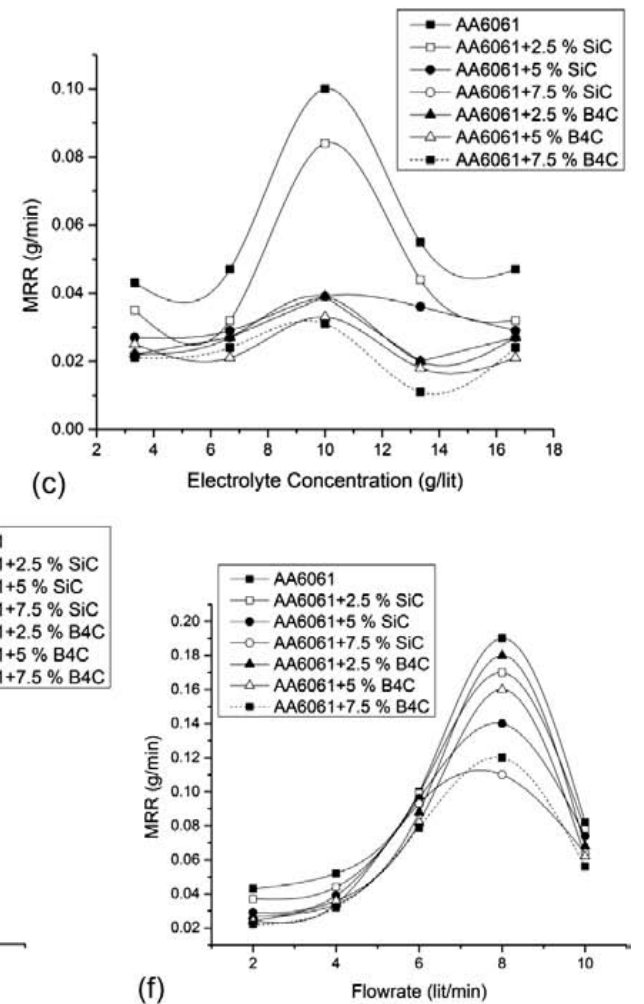

Figure 7: Influencing parameters with $M R R$ : a) current, b) voltage, c) electrolyte concentrations, d) feed rate, e) gap, f) flow rate Slika 7: Parametri, ki vplivajo na MRR: a) tok, b) napetost, c) koncentracija elektrolita, d) hitrost podajanja, e) reža, f) hitrost pretoka 
finish was obtained with a proper gap and a minimum feed rate. The feed rate was increased when the surface roughness of the workpiece was reduced.

The value of $S R$ for different levels of gap is plotted and shown in Figure 8e. The optimal value of the inter electrode gap was maintained for a better surface roughness. The minimium electrode gap produced the minimum material removal rate and hence provided a good surface finish. A high surface roughness was obtained for a $0.2 \mathrm{~mm}$ gap and the surface finish was reduced with increases in the gap between the tool and the workpiece.

The electrolyte flow rate governs the surface finish in the right way. The influence of flow rate on $S R$ was shown in Figure 8f. A very low flow rate creates a poor surface finish due to the non-flushing of the chip materials on the surface of the workpiece. A good surface roughness was obtained at a $6 \mathrm{~L} / \mathrm{min}$ flow of electrolyte. The flushing pressure was high for very high electrolyte flow condtions like $10 \mathrm{~L} / \mathrm{min}$. A very high flushing pressure tends to produce a vertex on the machining zone, and it will produce abrasive action on the surface of the machined zone. Hence, under high flow rate conditions, the surface roughness was compatively low.

\subsubsection{Factors influencing radial overcut}

The $R O C$ values obtained at different levels of current for the selected samples are shown in Figure 9a. The $R O C$ was increased with an increase in the current. If the current was low then the minimum material was removed from the surface of the machined zone. Hence, the $R O C$ was low. When the current was increased gradually, then the $R O C$ was increased. When a high current was applied in between the tool and the workpiece, then the maximum amount of material was removed from the workpiece and a high $R O C$ was produced.

The influence of the applied voltage on the $R O C$ is shown in Figure 9b. When the applied voltage between the electrodes was high, a high $R O C$ was obtained. The optimal value of the $R O C$ was achieved at a $12 \mathrm{~V}$ potential difference. At very low and very high voltages the flow of electrons through the electrodes is improper and hence it will tend to produce a variable machining rate. So the extreme levels of voltages were produced maximum $R O C$ and minimum $R O C$ was happened at midrange values.

The effects of the electrolyte concentration on radial overcut for different AMCs are shown in Figure 9c. When the electrolyte concentration was high, the ROC was low. High lubrication was provided in a high concentration of electrolyte solutions and hence a better surface finish was obtained. The concentrated electrolyte solution has a good number of ions that will act as the catalyst to improve the reaction between the electrode and the workpiece. In the above condition an enormous amount of hydrogen was generated and an unwanted reaction in the machining zone was avoided. So, the minimum ROC was obtained with high electrolyte concentrations.

The influence of feed rate on the $R O C$ is shown in Figure 9d. The material removal rate and the $R O C$ were directly proportional to each other. The higher feed rate of the tools produced a poor surface roughness and a high material removal rate. The higher rate of material removal from the workpiece increased the $R O C$. The (a)

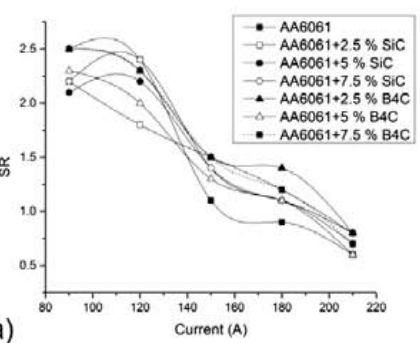

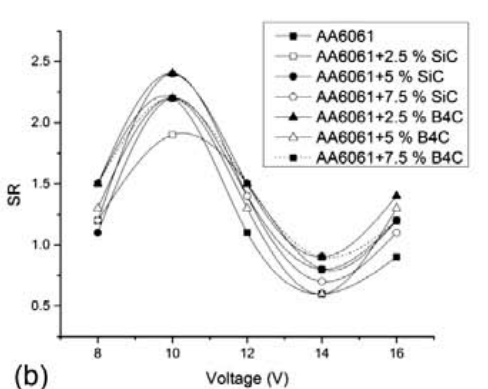

(b)

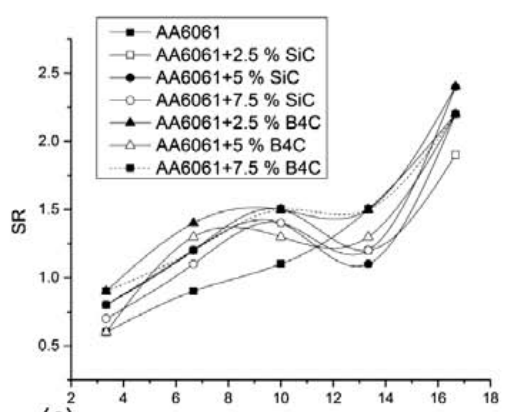

(c)
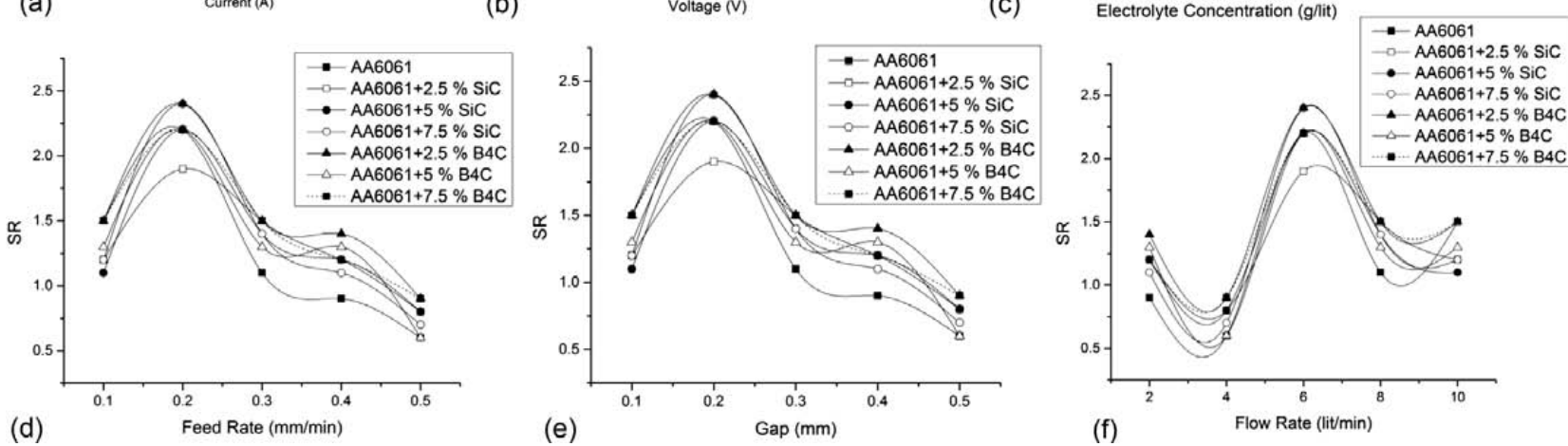

Figure 8: Influencing parameters with $S R$ : a) current, b) voltage, c) electrolyte concentrations, d) feed rate, e) gap, f) flow rate Slika 8: Parametri, ki vplivajo na $S R$ : a) tok, b) napetost, c) koncentracija elektrolita, d) hitrost podajanja, e) reža, f) hitrost pretoka 

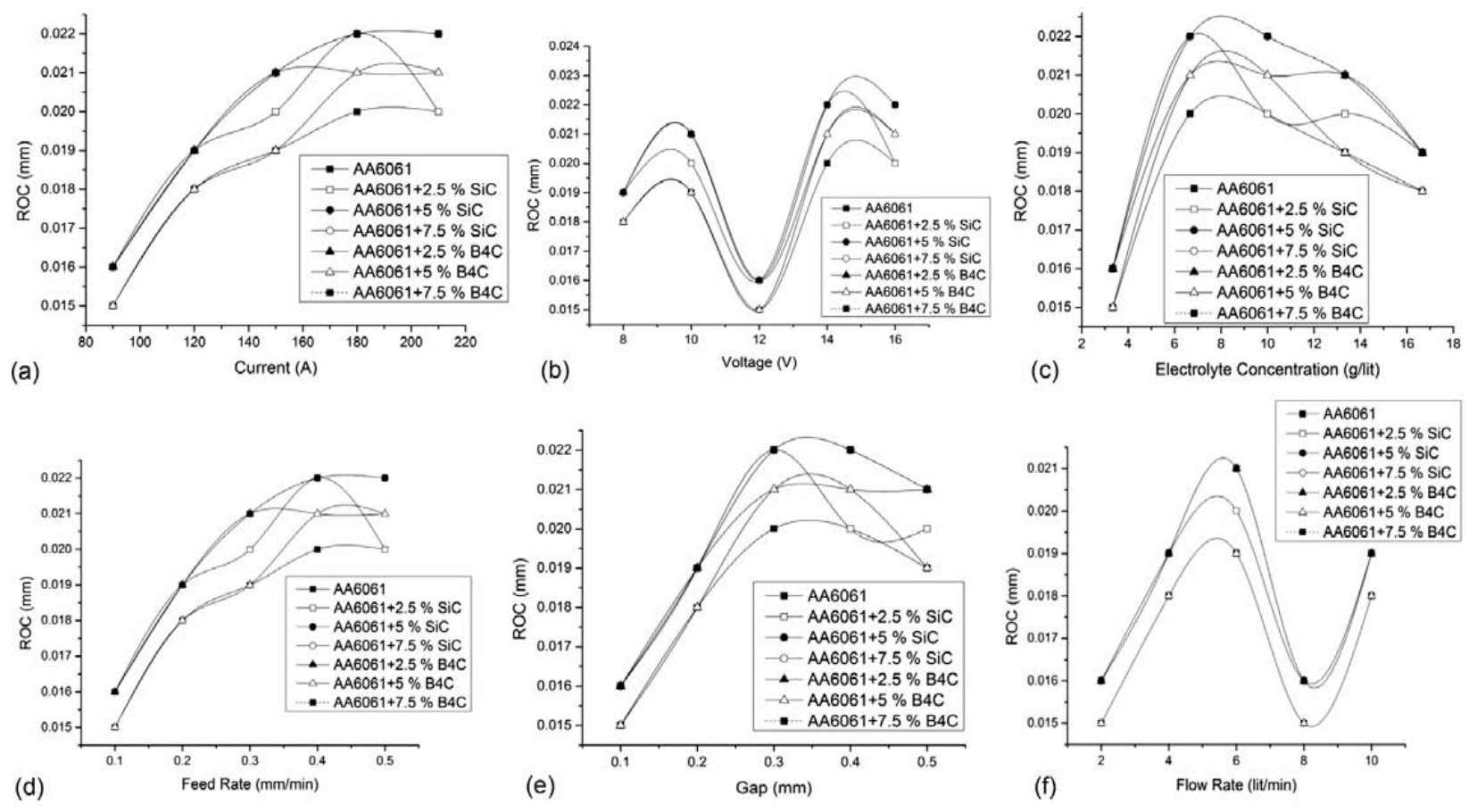

(d)

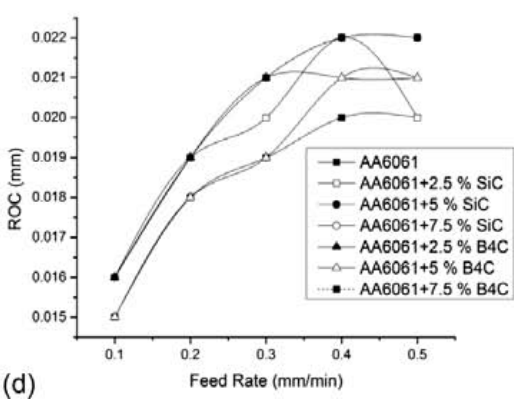

Figure 9: Influencing parameters with $R O C$ : a) current, b) voltage, c) electrolyte concentrations, d) feed rate, e) gap, f) flow rate Slika 9: Parametri, ki vplivajo na $R O C$ : a) tok, b) napetost, c) koncentracija elektrolita, d) hitrost podajanja, e) reža, f) hitrost pretoka

$R O C$ was high at a very high range of the tool feed on the workpiece. The $R O C$ values obtained in the different gaps for the selected samples were plotted in Figure 9e. The inter electrode gap was maintained with an optimal range of values. If the gap between the tool and the workpiece was too low, then the contact took place and the very minimum material was removed from the workpiece. Hence, the $R O C$ in the low gap was a minimum. The spark in between the tool and the workpiece material might be produced because of an improper gap and irregular machining on the workpiece. Due to the irregular machining the $R O C$ was very high.

The influence of flow rate on $R O C$ is shown in Figure 9f. When the flow of the electrolyte was very low then the sludge was stagnated at the machining zone. Further machining was on the chip with a new machining surface and a poor surface finish leads to high $R O C$. Similarly, the high velocity of the stream of electrolyte created the flow of the abrasive action with sludge chips and hence the $R O C$ was increased. The optimal flow of electrolyte was needed for the proper removal of sludge formation and good machining accuracy.

\section{CONCLUSION}

In this paper the microstructure and mechanical properties of AA6061 reinforced with silicon carbide and AA6061 reinforced with boron carbide obtained from an enhanced stir-casting method was investigated. Three different weight percentages, i.e., $2.5 \%, 5 \%$ and $7.5 \%$, of silicon carbide and boron carbide were used for the reinforcement. The presence of silicon- and boron-based particles employs a key role in the microstructure development of the composites. The ductility of the AA6061 was increased in both the reinforced AMCs with significantly good tensile properties. The microhardness was markedly influenced by both the alloying elements. From the study it was observed that the selected AMCs were suitable for unconventional machining process like electrochemical machining. In ECM the input parameters influence the output variables Material Removal Rate $(M R R)$, Surface Roughness $(S R)$ and Radial Overcut $(R O C)$. The higher input parameters increased the Material Removal Rate. The higher value of Material Removal Rate during the machining produced poor-surface-quality materials. The $R O$ was also in close agreement with the $S R$.

\section{Acknowledgement}

The author gratefully acknowledges the contributions of National Institute for Interdisciplinary Science and Technology Trivandrum, National Institute of Technology Trichy and Annamalai University Chithambaram.

\section{REFERENCES}

${ }^{1}$ K. P. Rajurkar Sekar. T. Marappan, R. Experimental investigations into the influencing parameters of electrochemical machining of AISI 202, Journal of Advanced Manufacturing Systems, 7 (2008) 2, 337-43, doi:10.1142/S0219686708001486

${ }^{2}$ A. DeBarr, D. A. Eand Oliver, Electro-chemical Machining, Macdonald \& Co. Ltd, 1968

${ }^{3}$ Metals Handbook, Vol. 16, Machining, ASM International, Materials Park, OH 1989 
${ }^{4}$ S. K. Mukherjee, S. Kumar, P. Shrivastava, A. Kumar, Effect of valency on material removal rate in electrochemical machining of aluminium, Journal of Materials Processing Technology, 202 (2008), 398-401, doi:10.1016/j.jmatprotec.2007.09.065

${ }^{5}$ J. A. Westley, J. Atkinson, A. Duffield, Generic aspects of tool design for electrochemical machining, Journal of Materials Processing Technology, 149 (2004), 384-392, doi:10.1016/j.jmatprotec.2004. 02.046

${ }^{6}$ S. Dhar, R. Purohit, N. Saini, A. Sharma, G. H. Kumar, Mathematical modelling of electric discharge machining of cast Al-4Cu-6Si alloy-10 wt.\% SiCp composites, Journal of Materials Processing Technology, 194 (2007), 24-29, doi:10.1016/j.jmatprotec. 2007.03.121

${ }^{7}$ C. Senthilkumar, G. Ganesan, R. Karthikeyan, Study of electrochemical machining characteristics of $\mathrm{Al} / \mathrm{SiCp}$ composites, Journal of Materials Processing Technology, 43 (2009), 256-263, doi:10.1007/ s00170-008-1704-1

${ }^{8}$ T. Masuzawa, H. K. Tonshof, Three Dimensional Micro Machining by Machine Tools, Annals of CIRP, 42 (1997) 2, 621-628, doi:10.1016/S0007-8506(07)60882-8

${ }^{9}$ A. F. Rashed, H. Youssef, H. El-Hofy, Effect of Some Process Parameters on the Side Machining During Electrolytic Sinking, PEDAC-3 Conf., Alexandria, 1986, 733-746

${ }^{10}$ J. C. da Silva Neto, E. M. da Silva, M. B. da Silva, Interventing variables in electrochemical machining, Journal of Materials Processing Technology, 179 (2006) 1-3, 92-96, doi:10.1016/ j.jmatprotec.2006.03.105

${ }^{11}$ H. Youssef, H. El-Hofy, Y. El-Mehdawy, Sparking Phenomena and Hole Oversize by ECM, Effect of Some Process Parameters, Alexandria Engineering Journal, 28 (1989) 4, 247-259

${ }^{12}$ M. Datta, R. V. Shenoy, L. T. Romatkiw, Recent Advances in the Study of Electrochemical Micromachining, Journal of Engineering for Industry, 118 (1996), 29-36, doi:10.1115/1.2803644

${ }^{13}$ T. W. Clyne, P. J. Withers, An introduction to metal matrix composites, Cambridge University Press, 1993

${ }^{14}$ K. K. Chawla, Composite materials-science and engineering, Springer-Verlag, New York (1998) 2, 165-211, doi:10.1007/978-0-38774365-3_1

${ }^{15}$ D. L. McDanels, Analysis of stress-strain, fracture, and ductility behavior of aluminium matrix composites containing discontinuous silicon carbide reinforcement, Metall Trans A, 16 (1985), 1105-15, doi:10.1007/BF02811679

${ }^{16}$ F. Toptan, A. Kilicarslan, M. Cigdem, I. Kertil, Processing and micro structural characterization of AA 1070 and AA 6063 matrix B4C reinforced composites, Advanced Component Manufacture from Light Materials International Conference on Materials for Advanced Technologies, 31 (2010) 1, 87-91, doi:10.1016/j.matdes.2009.11.064
${ }^{17}$ C. San Marchia, M. Kouzelia, R. Raoc, J. A. Lewisc, D. C. Dunanda, Alumina-Aluminum Interpenetrating Phase Composites With Three Dimensional Periodic Architecture, Journal of Scripta Materialia, 49 (2003) 9, 861-866, doi:10.1016/S1359-6462(03)00441-X

${ }^{18}$ T. M. Chenthil Jegan, D. Ravindran, M. Dev Anand, Material Characterization Study on Aluminium Metal Matrix Composites by Enhanced Stir Casting Method, Advanced Materials Research, 984-985 (2014), 326-330, doi:10.4028/www.scientific.net/AMR. 984-985.326

${ }^{19}$ K. M. Shorowordi, T. Laoui, A. S. M. A. Haseeb, J. P. Celis, L. Froyen, Microstructure and interface characteristics of $\mathrm{B}_{4} \mathrm{C}, \mathrm{SiC}$, $\mathrm{Al}_{2} \mathrm{O}_{3}$ reinforced $\mathrm{Al}$ matrix composites: a comparative study, J. Mater. Process. Technol., 142 (2003), 738-743, doi:10.1016/S09240136(03)00815-X

${ }^{20}$ L. E. G. Cambronero, E. Sanchez, J. M. Ruiz-Roman, J. M. RuizPrieto, Mechanical characterization of AA7015 aluminum alloy reinforced with ceramics, Proceedings of the International Conference on the Advanced Materials Processing Technology, 143-144 (2003), 378-383, doi:10.1016/S0924-0136(03)00424-2

${ }^{21}$ E. Mart, A. Forn, R. Nogue, Strain hardening behaviour and temperature effect on Al-2124/SiCp, Proceedings of the International Conference on the Advanced Materials Processing Technology, 143-144 (2003), 1-4, doi:10.1016/S0924-0136(03)00292-9

${ }^{22}$ J. S. Kwak, Y. S. Kim, Mechanical properties and grinding performance on aluminum-based metalmatrix composites, Journal of Materials Processing Technology, 201 (2008) 1-3, 596-600, doi:10.1016/ j.jmatprotec.2007.11.139

${ }^{23}$ M. Tan, Q. Xin, L. Zhenghua, B. Y. Zong, Influence of SiC and $\mathrm{Al}_{2} \mathrm{O}_{3}$ particulate reinforcements and heat treatments on mechanical properties and damage evolution of Al-2618 metal matrix composites, Journal of Materials Science, 36 (2001), 2045-2053, doi:10.1023/A:1017591117670

${ }^{24}$ D. T. Chung, Development of new actuators for flapping wing flight, Materials Science Forum, 543 (2007), 36-41, doi:10.4028/ www.scientific.net/MSF.539-543.36

${ }^{25}$ P. T. B. Shaffer, Engineered Materials Handbook, 4, 1991, 804-810

${ }^{26}$ I. Kerti, F. Toptan, Microstructural variations in cast $\mathrm{B}_{4} \mathrm{C}$-reinforced aluminium matrix composites (AMCs), Journal of Materials Letters, 62 (2008) 8-9, 1215-1218, doi:10.1016/j.matlet.2007.08.015

${ }^{27}$ J. Hashim, L. Looney, M. S. J. Hashmi, Metal matrix composites: production by the stir casting method, Journal of Materials Processing Technology, 92-93 (1999), 1-7, doi:10.1016/S0924-0136(99) 00118-1 